\title{
ENHANCING NURSE ENGAGEMENT: THE ROLE OF SOCIAL SUPPORT AND JOB CHARACTERISTICS
}

\author{
Noraini Othman \\ School of Business Management, College of Business, Universiti Utara Malaysia, 06010 UUM, \\ Sintok, Kedah Darulaman, Malaysia; n.aini@uum.edu.my \\ Zahiruddin Ghazali \\ Othman Yeop Abdullah Graduate School of Business, Universiti Utara Malaysia, 06010 UUM, Sintok, \\ Kedah Darulaman, Malaysia; uddin@uum.edu.my \\ Aizzat Mohd Nasurdin \\ School of Management, Universiti Sains Malaysia, 11800 Pulau Pinang, Malaysia; aizzat@usm.my
}

\begin{abstract}
Nursing work engagement has become an increasingly crucial factor and a condition for high-quality health care performance, thus influencing the success of the organization. As the nursing profession is regarded as an emotionally demanding work environment, nurses as boundary-spanners of health care institutions need to have adequate job resources. This study examined the relationship between job resources consisting of social support, job feedback, task significance and work engagement. The sample comprised of 345 staff nurses working in three public hospitals in Peninsular Malaysia. Statistical results using hierarchical linear regression analysis shown that supervisor support, job feedback, and task significance were positively related to work engagement. In contrast, co-worker support has no significant relationship with work engagement.
\end{abstract}

Keywords: work engagement, job resources, social support, job feedback, task significance

\section{Introduction}

Malaysia aims to be a developed country by 2020 . To increase its economic growth, the government continues its effort in its Eleventh Malaysia Plan (2016-2020) by enhancing the fundamentals of health care system (Economic Planning Unit, 2017). However, this agenda might not be achieved as the country is facing shortage of nurses. Malaysian current nurse-to-patient ratio is 1:325 which is far below the 1:200 ratio recommended by the World Health Organization (Economic Planning Unit, 2017). Therefore, the need to employ sufficient and qualified nurses is more severe for Malaysia, mostly in public hospitals. As nurses represent frontline employees and play the role of boundary spanners, they have a significant role in care delivery and health quality.

Purdy et al. (2010) and Chen et al. (2009) argued that nursing is an important profession to study because nurses' performance has a great impact on the nature and quality of service provided to the patients. Previous studies have found nurses' attitudes and behaviours as significant in determining the quality of healthcare services (Cohen \& Golan, 2007; Al-Ahmadi, 2008). According to Moritz et al. (1989), nurses' attitudes and behaviours toward patients would significantly affect patients' perceived service quality and satisfaction. Moreover, the quality of nursing care has a strong effect on healthcare organizations' ability to provide services at the desired professional standard (Moritz et al., 1989; McSherry \& Douglas, 2011).

For that reason, nurses should perform in favourable attitude in the form of work engagement. Work engagement is defined as a positive, fulfilling, work-related state of mind that is characterized by vigor, dedication and absorption (Schaufeli \& Bakker, 2004). Vigor is a state where individual experiences a high degree of energy, a strong work ethic and an ability to persevere when confronted with challenging work (Schaufeli \& Bakker, 2004). Dedicated individuals have an enthusiastic attitude and being motivated and proud of their work. Absorption in work entails being fully immersed in work and feeling happy about one's work roles. Seligman and Csikszentmihalyi (2000) proposed that work engagement has been recognized as one of the positive states, which is the opposite of burnout based 
on the emergence of positive psychology - the scientific study of human strength and optimal functioning.

According to Schaufeli et al. (2006), engaged employees have a sense of energetic and effective relation with their job, more productive as they often experienced positive emotions, and more likely to perceive that they can manage their job demands. In nursing context, the concept of nurse engagement is regularly used to describe nurses' commitment and satisfaction with their jobs. As nurse engagement relates directly with critical safety, high-quality health care performance, and patient experience outcomes (Day, 2014; Nishioka et al., 2014; Horner et al., 2011) understanding the present state of nurse engagement and its predictors are vital (Dempsey \& Reilly, 2016).

Several studies examined the motivational influence of work engagement on employees in numerous settings, for example, manufacturing employees, service members, nurses, leaders and followers (Tan et al. 2016; Delahaij et al. 2016; Wang et al. 2017; Chen, 2015). These studies demonstrate that engaged employees display better job outcomes. Hence, to foster high work engagement within the nursing workforce, nurses need to have sufficient job resources in doing their jobs. Job resources refer to those aspects of the job that may: (a) lessen job demands and the associated physiological and psychological costs, (b) be functional in attaining work goals, and (c) encourage employees' growth, learning, and development (Bakker \& Demerouti, 2007; Schaufeli \& Bakker, 2004). As argued by Bakker and Demerouti (2007), job resources are presumed to have motivational potentials that eventually result in positive work outcomes such as greater engagement.

At workplace, job resources play two main roles: extrinsic motivators and intrinsic motivators. Extrinsically, since job resources such as social support from peers are instrumental in the accomplishment of work goals, they aid in the creation of a resourceful work environment (Meijiman \& Mulder, 1998). Intrinsically, according to scholars (Bakker et al., 2007; Deci \& Ryan, 1985), the availability of certain job resources such as social support helps fulfil basic human needs while some such as job latitude promotes employees' capacity to grow, learn, and develop. The job resources' intrinsic motivational potential is also recognized by job characteristics theory developed by Hackman and Oldham (1980). In addition, Schaufeli and Salanova (2007) noted that job characteristics theory by Hackman and Oldham (1980) is the most explicit theory in predicting strategies of redesigning jobs that have positive effects on employee well-being, motivation and performance.

Past researchers (e.g., Othman \& Mohd Nasurdin, 2013; Johari et al., 2016; Othman et al., 2015; 2017) who asserted that positive perception of personal resources and job resources will lead to higher work engagement. Othman and Mohd Nasurdin (2013) conducted a study on a sample of 402 staff nurses from three general hospitals in Peninsular Malaysia. Their results indicated that supervisor support positively and significantly associated with nurses' work engagement. However, co-worker support was found unrelated to work engagement. Meanwhile, a meta-analytic study by Christian et al., (2011) revealed that job resources in the form of autonomy, feedback, task significance, task variety, job complexity, problem-solving, and social support were positively related to work engagement. Similarly, Bakker and Bal (2010) conducted a study among 56 Dutch college teachers also found that job resources comprising of autonomy, performance feedback, learning opportunities, and supervisory coaching were positively associated with weekly work engagement. Moreover, Salanova and Schaufeli (2008) in their study on 386 Spanish technology employees and 338 Dutch telecom managers showed positive significant relationship between job resources (job control, task variety, and feedback) and work engagement. In a longitudinal study by Mauno et al. (2007), involving 409 Finnish healthcare employees discovered that job resources predicted work engagement better than job demands. In addition, Schaufeli and Bakker (2004) conducted a study among employees from four different Dutch service organizations: an insurance company, a pension fund company, an occupational health and safety service and a home-care institution. In their study, job resources which include social support from colleagues and performance feedback were found to be associated with work engagement. According to social exchange theory (Blau, 1964), employees perceive that their supervisor supports and cares for their well-being, they would feel attached to the organization and feel obligated to "return the favour" to their supervisor by staying in the organization. In line with the extant literature and consistent with the job characteristics theory (Hackman \& Oldham, 1980), our hypotheses are as follows:

Hypothesis 1: Supervisor Support is positively related to work engagement

Hypothesis 2: Co-worker Support is positively related to work engagement 
Hypothesis 3: Job Feedback is positively related to work engagement

Hypothesis 4: Task Significance is positively related to work engagement

\section{Methodology}

For the purpose of the present study, a cross-sectional study was conducted in three public hospitals in Peninsular Malaysia. Respondents in this study comprised of staff nurses working in these participating hospitals. A total of 415 questionnaires were distributed with the assistance of the Matron Office of the three hospitals. The distribution and collection of the completed questionnaires took about one month. Of the 415 questionnaires distributed, only 345 questionnaires were returned, yielding a response rate of $83.13 \%$.

\section{Measures}

Work engagement was measured using the shortened nine-item version of the Utrecht work engagement scale (UWES-9) developed by Schaufeli and Bakker (2003). This UWES-9 consists of three underlying dimensions, which are measured with three items each: vigor, dedication and absorption. Item responses were on a seven-point Likert scale ranging from $1=$ "never" to $7=$ "always". The Cronbach's alpha coefficient for this scale is 0.90 . A scale by Susskind et al. (2003) which include supervisor support (4 items) and co-worker support (3 items) were used to measure social support. All items were measured on a seven-point Likert scale ranging from 1 = "strongly disagree" to 7 = "strongly agree". Cronbach's alpha for these two types of supports were 0.95 and 0.94 , respectively. Meanwhile, job characteristics (job feedback and task significance) were measured with the corresponding subscales of the Job Diagnostic Survey (JDS: Hackman and Oldham, 1975, 1980). Each subscale comprised of three items that were evaluated by the respondents based on a seven-point Likert-scale ranging from 1 = "very inaccurate" to 7 = "very accurate". Cronbach's alpha for these scales were 0.74 (job feedback), and 0.64 (task significance). Demographic information such as gender, marital status, age, race, and job tenure were also requested.

\section{Results}

Table 1 shows some of the demographic characteristics of the sample. Majority of the staff nurses were females $(98.3 \%)$ and married $(74.2 \%)$, with ages ranging from 23 to 58 years $(\mathrm{M}=33.12, \mathrm{SD}=8.44)$. The mean length of time working as a staff nurse was 9.20 years $(\mathrm{SD}=7.85)$. In terms of ethnicity, most of the respondents were Malays (91.3\%), followed by Indians (5.2\%), and Chinese (3.5\%).

Table 1: Profile of Respondents

\begin{tabular}{|c|c|c|c|}
\hline $\begin{array}{c}\text { Demographic } \\
\text { Factor }\end{array}$ & Category & Frequency & $\begin{array}{c}\text { Percentage } \\
(\%)\end{array}$ \\
\hline Gender & Female & 339 & 98.3 \\
& Male & 6 & 1.7 \\
\hline Marital Status & Married & 256 & 74.2 \\
& Unmarried & 89 & 25.8 \\
\hline Ethnicity & Malay & 315 & 91.3 \\
& Indian & 18 & 5.2 \\
& Chinese & 12 & 3.5 \\
\hline Age (yr.) & Mean & Standard Deviation \\
\hline Job Tenure (yr.) & 9.20 & \multicolumn{2}{|c|}{8.44} \\
& 33.12 & \multicolumn{2}{|c}{} \\
\hline
\end{tabular}

As presented in Table 2, on the average, task significance $(\mathrm{M}=6.09, \mathrm{SD}=0.90)$ was perceived high by the nurses. The level of co-worker support $(\mathrm{M}=5.66, \mathrm{SD}=0.83)$, job feedback $(\mathrm{M}=5.65, \mathrm{SD}$ 
$=0.79)$, and work engagement $(\mathrm{M}=5.18, \mathrm{SD}=0.80)$ were slightly high. On the other hand, the mean value for supervisor support $(\mathrm{M}=4.76, \mathrm{SD}=0.95)$ was found to be moderate. The reliability coefficients for the study variables were above 0.70 , which meets the minimum acceptable standard of 0.7 for exploratory research as suggested by Hair et al. (2006). Meanwhile, correlations between the study variables were found to be significant $(\mathrm{p}<0.01)$, except correlation between task significance and supervisor support.

Table 2: Descriptive Statistics, Correlations, and Reliabilities of the Study Variables

\begin{tabular}{|l|l|l|l|}
\hline Variables & Mean & $\begin{array}{l}\text { Standard } \\
\text { Deviation }\end{array}$ & $\begin{array}{l}\text { W o r k } \\
\text { Engagement }\end{array}$ \\
\hline $\begin{array}{l}\text { W o r k } \\
\text { Engagement }\end{array}$ & 5.18 & 0.80 & $(0.85)$ \\
\hline $\begin{array}{l}\text { Supervis or } \\
\text { Support }\end{array}$ & 4.76 & 0.95 & $0.30^{* *}$ \\
\hline $\begin{array}{l}\text { Co-worker } \\
\text { Support }\end{array}$ & 5.66 & 0.83 & $0.19^{* *}$ \\
\hline $\begin{array}{l}\text { J o b } \\
\text { Feedback }\end{array}$ & 5.65 & 0.79 & $0.41^{* *}$ \\
\hline $\begin{array}{l}\text { T a s k } \\
\text { Significance }\end{array}$ & 6.09 & 0.90 & $0.28^{* *}$ \\
\hline
\end{tabular}

\begin{tabular}{|l|l|l|l|}
\hline $\begin{array}{l}\text { Supervisor } \\
\text { Support }\end{array}$ & $\begin{array}{l}\text { Co-worker } \\
\text { Support }\end{array}$ & $\begin{array}{l}\text { J o beedback } \\
\text { Fe }\end{array}$ & $\begin{array}{l}\text { T a s k } \\
\text { Significan } \\
\text { ce }\end{array}$ \\
\hline$(0.74)$ & & & \\
\hline $0.33^{* *}$ & $(0.71)$ & & \\
\hline $0.25^{* *}$ & $0.41^{* *}$ & $(0.74)$ & \\
\hline 0.10 & $0.27^{* *}$ & $0.39^{* *}$ & $(0.86)$ \\
\hline
\end{tabular}

Note: ${ }^{* *} \mathrm{p}<0.01, * \mathrm{p}<0.05$. Figures in parentheses denote the reliability coefficients for the study variables.

Hierarchical linear regression analysis was performed to examine the relationship between supervisor support, co-worker support, job feedback, task significance, and work engagement. Demographic factors such as age, marital status, and job tenure were statistically controlled (Koyuncu et al., 2006; Mauno et al., 2007).

As displayed in Table 3, based on model 1, the control variables accounted for $4 \%$ of the variance in work engagement $\left(\mathrm{r}^{2}=0.040, f\right.$-change $\left.=4.724, \mathrm{p}<0.01\right)$. All the three control variables were insignificantly related to work engagement. This indicates that the three control variables did not make any significant contribution towards the variance in nurses' work engagement. In model 2, by adding the predictor variables, the $\mathrm{r}^{2}$ increased to 0.247 . This result shows that the predictor variables were able to explain an additional $20.7 \%$ of the variance related with work engagement $\left(\mathrm{r}^{2}\right.$ change $=$ $0.207, f$-change $=23.129, \mathrm{p}<0.01)$. Supervisor support $(\beta=0.205, \mathrm{p}<0.01)$, job feedback $(\beta=0.311$, $\mathrm{p}<0.01)$, and task significance $(\beta=0.139, \mathrm{p}<0.01)$ were found to have a positive and significant relationship with work engagement, hence $\mathrm{H} 1, \mathrm{H} 3$, and $\mathrm{H} 4$ were supported. In contrast, co-worker support was found to have no significant relationship with work engagement, thus $\mathrm{H} 2$ was not supported. 
The Turkish Online Journal of Design, Art and Communication - TOJDAC

ISSN: 2146-5193, September 2018 Special Edition, p.1285-1292

Table 3: Results of Regression Analysis

\begin{tabular}{|c|c|c|}
\hline \multirow[t]{2}{*}{ Independent Variables } & \multicolumn{2}{|c|}{ Work Engagement } \\
\hline & $\begin{array}{l}\text { Model } 1 \\
\text { Std. B }\end{array}$ & $\begin{array}{c}\text { Model } 2 \\
\text { Std. } \beta\end{array}$ \\
\hline $\begin{array}{l}\text { Step 1: Control Variable } \\
\text { Age } \\
\text { Marital Status } \\
\text { Job Tenure }\end{array}$ & $\begin{array}{r}-0.012 \\
-0.032 \\
0.217\end{array}$ & $\begin{array}{r}-0.053 \\
-0.021 \\
0.181\end{array}$ \\
\hline $\begin{array}{c}\text { Step 2: Predictor Variabl } \\
\text { Supervisor Support } \\
\text { Co-worker Support } \\
\text { Job Feedback } \\
\text { Task Significance }\end{array}$ & & $\begin{array}{l}0.205 * * \\
-0.040 \\
0.311 * * \\
0.139 * *\end{array}$ \\
\hline $\begin{array}{l}\mathrm{F} \text { value } \\
\mathrm{R}^{2} \\
\text { Adjusted } \mathrm{R}^{2} \\
\mathrm{R}^{2} \text { change } \\
\text { F-change }\end{array}$ & $\begin{array}{l}4.724 \\
0.040 \\
0.031 \\
0.040 \\
\quad 4.724 * *\end{array}$ & $\begin{array}{l}15.767 \\
0.247 \\
0.231 \\
0.207 \\
\quad 23.129 * *\end{array}$ \\
\hline
\end{tabular}

\section{Discussion}

The main purpose of this study was to investigate the effect of supervisor support, co-worker support, job feedback, task significance on work engagement. Findings found that supervisor support, job feedback, and task significance were significant predictors of work engagement. The findings imply that nurses who perceived high supervisor support and task significance in their jobs would exhibit higher work engagement. Similarly, nurses who perceived they are given sufficient job feedback would also display greater work engagement. This result is consistent with those of previous researchers (Othman \& Mohd Nasurdin, 2013; Christian et al., 2011; Bakker \& Bal, 2010; Salanova \& Schaufeli, 2008; Mauno et al., 2007). As nursing profession is regarded as an emotionally demanding work environment, the quality of teamwork and co-worker support is very important (Van der heijden, 2008; Sherony \& Green, 2002). Employees who observe a high level of co-worker support will view the workplace as a supportive environment, which they have abundant of opportunities to learn from their co-workers.

However, the results of this study revealed that co-worker support had no significant relationship with work engagement. It seems that high co-worker support among public hospital nurses may not be manifested into greater work engagement. One possible reason for this non-relationship could due to the healthcare practice environment. The role of a nurse has become more complicated, and is related to various responsibilities (Mrayyan, 2006). As boundary-spanners, nurses must deal with lots of people around them, such as hospital administrations, doctors, patients, supervisors, and co-workers; hence, these nurses may not be able to develop a closer relationship with their co-worker. Furthermore, their tight and busy work schedule may restrict them from providing support to their coworkers. These may have accounted for the non-relationship between co-worker support and work engagement. Thus, the hospital administrations should provide adequate job resources (supervisor support, job feedback, and task significance) to enhance nurses' work engagement, and in turn, leads to better job performance. 
As for implications, since supervisor support, co-worker support, job feedback, task significance influences work engagement, it would be worthwhile for hospital administrations and the Ministry of Health to provide a conducive nursing work environment. The findings suggested the importance of these job resources in promoting work engagement among staff nurses. To enhance work engagement, public hospital administrations should provide the necessary job resources for staff nurses to enable them to become more engaged in their work. Specifically, the supervisors (sisters) should provide more support, such as showing concern for staff nurses' feelings and needs; provide help and information, and constructive feedback. Besides that, the public hospital administrations should also conduct frequent job feedback exercise. These are to ensure that staff nurses know how well they are performing. It is believed that good supervisory support and constructive feedback will enhance work engagement among public hospital nurses. As for task significance, public hospital administrations should always remind the staff nurses on how important their jobs are in providing quality care to the patients. This is because their attitudes and behaviours have a great impact on patients' health.

In terms of limitations, only four predictor variables were examined. Other job resources such as job control, rewards at work, organizational support, and others may play an important role in predicting work engagement. Future researchers may wish to expand the scope of this study by focusing on these variables. Moreover, this study is limited to staff nurses working in public hospitals in Peninsular Malaysia. The same research could be expanded and replicated among other healthcare personnel from public and private hospitals. A larger sample in the same industry would improve the generalization of the findings.

\section{Conclusion}

The findings of this study provide a theoretical framework for understanding the relations among job resources (social support, job characteristics) and work engagement. Results revealed that supervisor support, task feedback, and task significance were significant predictors in determining and enhancing work engagement of nurses in Malaysian public hospitals. It is believed that job resources can also play an extrinsic motivational role, as a resourceful work environment will create an individual's willingness to contribute their abilities and efforts to the work task. Therefore, hospital management should provide more resources to enable nurses to become more engaged in their job.

\section{Acknowledgements}

The authors gratefully acknowledge Malaysian of Higher Education (MOHE) and Universiti Utara Malaysia (UUM) for the FRGS grant to undertake this research. Appreciation is also extended to Malaysian Ministry of Health (MOH) for granting permission to conduct this research.

\section{References}

Al-Ahmadi, H. (2008). Factors affecting performance of hospital nurses in Riyadh Region, Saudi Arabia. International Journal of Health Care Quality Assurance, 22(1), 40-54.

Bakker, A. B. \& Demerouti, E. (2007). The job demands-resources model: state of the art. Journal of Managerial Psychology, 22(3), 309-328.

Bakker, A. B. \& Bal, P. M. (2010). Weekly work engagement and performance: a study among starting teachers. Journal of Occupational and Organizational Psychology, 83, 189-206.

Chen, S-L. (2015). The relationship of leader psychological capital and follower psychological capital, job engagement and job performance: a multilevel mediating perspective. The International Journal of Human Resource Management, 26(18), 2349-2365.

Chen, C. K., Lin, C., Wang, S. H. \& Hou, T. H. (2009). A study of job stress, stress coping strategies and job satisfaction for nurses working in middle-level hospital operating room. Journal of Nursing Research, 17(3), 199-211.

Christian, M. S., Garza, A. S. \& Slaughter, J. E. (2011). Work engagement: a quantitative review and test of its relations with task and contextual performance. Personnel Psychology, 64:89-136.

Cohen, A. \& Golan, R. (2007). Predicting absenteeism and turnover intentions by past absenteeism and work attitudes: an empirical examination of female employees in long term nursing care facilities. Career Development International, 12(5), 416-432.

Day, H. (2014). Engaging staff to deliver compassionate care and reduce harm. British Journal of Nursing, 23(18), 974-980.

Deci, E. L. \& Ryan, R. M. (1985). Intrinsic Motivation and Self-Determination in Human Behavior. New York: Plenum Press. 
Delahaij, R., Kamphuis, W. \& Van Den Berg, C.E. (2016). Keeping engaged during deployment: The interplay between self-efficacy, family support, and threat exposure. Military Psychology, 28(2), $78-88$

Demsey, C. \& Reilly, B.A. (2016). Nurse engagement: What are the contributing factors for success? Journal of Issues in Nursing, 21(1), 11p.

Economic Planning Unit (2017). Eleventh Malaysian Plan 2016-2020. Retrieved August, 1, 2017, from http://www.epu.gov.my/html/themes/epu/html/RMKE11/rmke11_english.html

Hackman, J. R. \& Oldham, G. R. (1980). Work Redesign. Reading, $\bar{M}$ A: Addison-Wesley.

Hair, J.F., Black, W.C., Babin, B.J., Anderson, R.E. \& Tatham, R.L. (2006). Multivariate Data Analysis (6 ${ }^{\text {th }}$ ed). NJ, USA: Pearson International Edition.

Horner, R.D., Szaflarski, J.P., Ying, J., Meganathan, K., Matthews, G., Schroer, B., Weber, D. \& Raphaelson, M. (2011). Physician work intensity among medical specialties: emerging evidence on its magnitude and composition. Medical Care, 49(11), 1007-1011.

Johari, J., Adnan, Z., Tan, F. Y., Yahya, K. K. \& Isa, S. N. (2013). Fostering Employee Engagement Through Human Resource Practices: A Case of Manufacturing Firms in Malaysia. Jurnal Pengurusan, 38, 15-26.

Koyuncu, M., Burke, R. J. \& Fiksenbaum, L. (2006). Work engagement among women managers and professionals in a Turkish bank: Potential antecedents and consequences. Equal Opportunities International, 25, 299-310.

Mauno, S., Kinnunen, U. \& Ruokolainen, M. (2007). Job demands and resources as antecedents of work engagement: A longitudinal study. Journal of Organizational Behavior, 70, 149-171.

McSherry, R. \& Douglas, M. (2011). Innovation in nursing practice: a means to tackling the global challenges facing nurses, midwives and nurse leaders and managers in the future. Journal of Nursing Management, 19, 165-169.

Meijiman, T. F. \& Mulder, G. (1998). Psychological aspects of workload. In: Drenth PJ, Thierry H, de Wolff CJ. Handbook of Work and Organizational Psychology, Erlbaum, Hove; 1998, p. 5-33.

Moritz, P., Hinshaw, A.S. \& Heinrich, J. (1989). Nursing resources and the delivery of the patient care: The national center for nursing research perspective. Journal of Nursing Administration, 19(5), 12-17.

Mrayyan, M.T. (2006). Jordanian nurses' job satisfaction, patients'satisfaction and quality of nursing care. International Nursing Review, 53(3), 224-230.

Nishioka, V.M., Coe, M.T., Hanita, M. \& Moscato, S.R. (2014). Dedicated education unit: Student perspectives. Nursing Education Perspectives, 35(5), 301-307.

Othman, N. \& Mohd Nasurdin, A. (2013). Social support and work engagement: a study of Malaysian nurses. Journal of Nursing Management, 21, 1083-1090.

Othman, N., Ghazali, Z., \& Ahmad, S. (2015). Working in the ward: The link between job resources and work engagement. Australian Journal of Basic and Applied Sciences, 9(37), 171-177.

Othman, N., Ghazali, Z., \& Ahmad, S. (2017). Work engagement in nursing: Do job demands and resources really matter? Science International (Lahore), 29(2), 411-415.

Purdy, N., Laschinger, H. K. S., Firiegan, J., Kerr, M. \& Olivera, F. (2010). Effects of work environments on nurse and patient outcomes. Journal of Nursing Management, 18, 901-913.

Salanova, M. \& Schaufeli, W. B. (2008). A cross-national study of work engagement as a mediator between job resources and proactive behaviour. International Journal of Human Resource Management, 9(1), 116-131.

Schaufeli, W.B. \& Bakker, A.B. (2003). UWES-Utrecht work engagement scale: test manual, Department of Psychology, Utrecht University, available at: www.schaufeli.com

Schaufeli, W.B. \& Bakker, A.B. (2004). Job demands, job resources and their relationship with burnout and engagement: a multi-sample study. Journal of Organizational Behaviour, 25, 293-315.

Schaufeli, W.B. \& Van Rhenen, W. (2006). About the role of positive and negative emotions in managers'well-being: A study using the Job-related Affective Well-being Scale (JAWS). Gedrag \& Organisatie, 19, 323-344.

Seligman, M.E.P. \& Csikszentmihalyi, M. (2000). Positive psychology. An introduction. American Psychologist, 55, 5-14.

Sherony, K.M. \& Green, S.G. (2002). Co-worker exchange: Relationships between co-workers, leadermember exchange, and work attitudes. Journal of Applied Psychology, 87, 542-548.

Susskind, A.M., Kacmar, K.M. \& Borchgrevink, C.P. (2003). Customer service providers' attitudes relating to customer service and customer satisfaction in the customer-server exchange (CSX). Journal of Applied Psychology, 88(1), 179-187. 
Tan, F. Y. \& Johari, J. \& Yahya, K. K. (2016). The Mediating Role of Learning Goal Orientation in the Relationship between Work Engagement and Innovative Work Behavior. International Review of Management and Marketing, 6(S7), 169-174.

Van der Heijden, B.I.J.M., Demerouti, E., Bakker, A.B., Hasselhorn, H.M. (2008). Work-home interference among nurses: Reciprocal relationships with job demands and health. Journal of Advanced Nursing, 62(5), 572-584.

Wang, X., Liu, L., Zou, F., Hao, J. \& Wu, H. (2017). Associations of occupational stressors, perceived organizational support, and psychological capital with work engagement among Chinese female nurses. BioMed Research International, Article ID 5284628. 